\title{
PENGARUH ETIKA KERJA, KEPEMIMPINAN DAN PROFESIONALISME TERHADAP KINERJA KARYAWAN PT LION AIR
}

\author{
Anik Ariyanti \\ STIE IPWIJA \\ ariyanti.anik@yahoo.co.id
}

\begin{abstract}
This study aims to determine the partial and simultaneous influence of work ethic, leadership and professionalism on employee performance of PT Lion Air. The research hypothesis is that the work ethic, leadership and professionalism partially and simultaneously affect the performance of employees of PT Lion Air. The method used in this research is descriptive verification. The sample in this study was 30 people, which was calculated by Slovin Formula. The result of research mentioned that work ethic, leadership and professionalism partially and simultaneously have a positive and significant effect on employee performance of PT Lion Air. From the value of Adjusted $R$ Square of 0.717 , it means that the three independent variables give the influence/contribution of $71.7 \%$ to the increase in performance, the remaining $28.3 \%$ influenced by other factors.
\end{abstract}

Keywords: Work ethic, leadership, professionalism and employee performance

\section{PENDAHULUAN}

\section{Latar Belakang Masalah}

Di era globalisasi saat ini, peranan sumber daya manusia menjadi faktor utama dalam menentukan keberhasilan perusahaan atau organisasi. Robert J. Eaton, CEO Chrysler Corporation, Amerika Serikat, mengatakan: "The only we can beat the competition is with people", yang artinya bahwa di tengah-tengah pesatnya kecanggihan teknologi, ternyata peran SDM dalam menentukan keberhasilan perusahaan tidak bisa diabaikan. Ibarat pepatah, SDM merupakan sumber keunggulan daya saing yang sangat dominan. Hal ini berbeda dengan teknologi produk dan proses produksi yang dinilai makin berkurang peran pentingnya sebagai sumber keunggulan daya saing.
PT Lion Air merupakan maskapai penerbangan swasta nasional asal Indonesia yang didirikan pada 15 November 1999 dan mulai beroperasi pertama kalinya pada 30 Juni 2000. Dalam perjalanannya, Lion Air telah banyak memiliki rangkaian prestasi dan penghargaan, serta sertifikasi internasional yang tentunya diraih untuk terus meningkatkan kualitas dalam pelayanannya kepada masyarakat dan pelanggan setianya. Beberapa di antaranya adalah sertifikasi ISSA yaitu sebuah standar keselamatan dan keamanan berskala internasional yang diberikan oleh IATA dan diraih pada Januari 2016, Lalu sertifikasi ISO 9001:2015 mengenai delay management yang tentunya standar tersebut akan terus diaudit secara berkala. 
Dalam upaya meningkatkan kualitas pelayanan pada masyarakat dan pelanggannya PT Lion Air membutuhkan sumber daya manusia yang berkualitas dan profesional, didukung pula dengan penerapan etika dalam bekerja. Menurut PT Lion Air, karyawan harus mengetahui pedoman dalam bekerja yang meliputi aturan normatif yang mengandung sistem nilai dan prinsip moral.

Etika kerja karyawan secara normatif diturunkan dari etika bisnis. Etika tidak diterapkan atau ditujukan untuk para karyawan saja. Karena kebijakan manajemen yang menyangkut karyawan seharusnya pula beretika, sehingga setiap keputusan etika dalam perusahaan tidak saja dikaitkan dengan kepentingan manajemen tetapi juga kepentingnan karyawan.

Peranan kepemimpinan sangat membantu pencapaian keberhasilan dalam organisasi atau perusahaan. Kepemimpinan merupakan salah faktor yang berpengaruh dalam meningkatkan kinerja karyawan. Kepemimpinan berhubungan dengan sikap, gaya, dan perilaku pimpinan sangat berpengaruh terhadap karyawan sehingga mampu mempengaruh kinerjanya. Keberhasilan suatu perusahaan sangat dipengaruhi oleh gaya kepemimpinan yang dipakai dalam perusahaan tersebut. Setiap pemimpin diharapkan mampu memberikan metode kepemimpinan yang dapat memberikan dampak signifikan pada penciptaan kinerja.
Profesionalisme kerja karyawan menjadi penunjang keberhasilan perusahaan. Untuk mencapai kinerja karyawan yang baik serta tercapainya tujuan perusahaan dibutuhkan sikap profesionalisme dari setiap karyawan. PT Lion Air mempunyai harapan bahwa profesionalisme dari karyawan dapat diukur dari knowledge, skill, dan integrity.

PT Lion Air mempunyai harapan agar hasil kerja/kinerja secara kualitas dan kuantitas akan tercapai. Keberhasilan kinerja perusahaan salah satunya ditentukan oleh kinerja para karyawannya. Kinerja yang buruk pada organisasi tidak lepas dari kinerja buruk dari karyawannya. Dalam mengatasinya perlu pendekatan yang disebut perencanaan peningkatan kinerja, yang merupakan teknik yang mengutamakan analisis atas kekuatan-kekuatan pendorong dan penghambat kinerja guna menentukan strategi untuk mencapai tujuan yang telah ditetapkan.

Dari beberapa uraian di atas, pada penelitian ini penulis ingin mengulas masalah yang berkaitan dengan etika kerja, kepemimpinan, profesionalisme dan pengaruhnya terhadap kinerja karyawan pada PT Lion Air. Adapun judul yang diajukan dalam penelitian ini adalah: "Pengaruh Etika Kerja, Kepemimpinan dan Profesionalisme terhadap Kinerja Karyawan PT Lion Air".

\section{Permasalahan}

Permasalahan pada penelitian ini adalah bagaimana etika kerja karyawan PT Lion Air 
selama ini, bagaimana kepemimpinan yang dipakai pada PT Lion Air, bagaimana tingkat profesionalisme karyawan dalam bekerja serta bagaimana tingkat kinerja selama ini apakah dengan adanya peningkatan pada etika kerja, kepemimpinan dan profesionalisme, maka kinerja akan meningkat.

\section{Tujuan}

Tujuan penelitian ini adalah untuk mengetahui pengaruh etika kerja, kepemimpinan dan profesionalisme secara parsial dan simultan terhadap kinerja karyawan PT Lion Air.

\section{Ruang Lingkup}

Ruang lingkup dalam penelitian ini berfokus pada masalah tingkat kinerja karyawan PT Lion Air, ditinjau dari faktor etika kerja karyawan, kepemimpinan yang digunakan dan tingkat profesionalisme karyawan.

\section{Rumusan Masalah}

Rumusan masalah penelitian ini adalah bagaimakah pengaruh etika kerja, kepemimpinan dan profesionalisme secara parsial dan simultan terhadap kinerja karyawan PT Lion Air.

\section{Manfaat Penelitian}

Penelitian ini diharapkan dapat bermanfaat:
a. Bagi Penulis dalam pemahaman terhadap etika kerja, kepemimpinan, profesionalisme dan kinerja.

b. Bagi Objek Penelitian, hasil penelitian ini mampu memberikan masukan kepada PT Lion Air untuk menentukan kebijakan dalam rangka meningkatkan kinerja karyawan melalui etika kerja, kepemimpinan dan profesionalisme.

c. Peneliti Lain, hasil penelitian ini sebagai referensi untuk penelitian lain yang mempunyai masalah yang sama yaitu tentang etika kerja, kepemimpinan, profesionalisme dan kinerja.

\section{TINJAUAN TEORI}

\section{Etika Kerja}

Etika kerja merupakan konsep yang mampu memandang sebuah pengabdian atau dedikasi seseorang terhadap pekerjaan sebagai nilai yang berharga. Etika kerja atau etos kerja adalah seperangkat perilaku kerja positif yang berasal pada kesadaran yang kental, keyakinan yang fundamental, disertai komitmen yang total pada paradigma kerja yang integral. (Sinamo, 2010)

Karyawan yang mempunyai etika kerja yang tinggi akan bekerja keras, tidak membuang-buang waktu selama bekerja, jujur, mau bekerja sama, percaya diri dan mempunyai tanggung jawab.

Beberapa faktor yang mempengaruhi etika kerja karyawan, adalah motivasi, penilaian prestasi. peraturan organisasi, pengaruh antar sesama rekan kerja, pengawasan, dan pembinaan. Menurut Novliadi (2009) menyebutkan beberapa 
faktor lain yang mempengaruh etika kerja yaitu: agama, social politik, pendidikan, struktur ekonomi, dan motivasi intrinsik individu.

Menurut Puspitasari (2009) dalam penelitiannya bahwa etika kerja adalah bagian dari tata nilai yang dimiliki seseorang yang diwujudkan dalam sikap dan tingkah lakunya dengan ciri-ciri: kedisiplinan, kejujuran, percaya diri, dan tanggungjawab terhadap tugasnya dalam suatu organisasi.

Untuk membangun etika kerja para karyawan, perusahaan harus membuat kode etika kerja dengan melibatkan karyawan, memberikan pelatihan tentang pengertian dan penerapan etika kerja, melaksanakan proses sosialisasi dan internalisasi etika kerja, meningkatkan komunikasi horizontal dan vertikal: formal dan informal, meningkatkan fungsi pengawasan kerja dan memberikan penghargaan kepada para karyawan yang beretika kerja tinggi sebagai motivasi bagi karyawan lainnya dalam meningkatkan etika kerjanya.

Etika kerja digunakan sebagai landasan untuk meningkatkan prestasi kerja atau kinerja. Landasan kerja ini harus dibudayakan oleh para karyawan agar secara eksplisit karyawan akan memiliki suatu budaya sikap kerja yang berorientasi pada hasil, dengan suatu keyakinan bahwa akan ada peningkatan terhadap hasil dan sesuai dengan tujuan yang telah ditetapkan bersama.
Beberapa prinsip etika kerja yang perlu diaplikasikan dalam perusahaan adalah: commitment, confidence, cooperative, care, creative, challenge, calculation, communication, competiveness, dan change. Karyawan yang menerapkan etika kerja mampunyai niat yang kuat dan tidak mudah menyerah dalam menghadapi masalah, mempunyai sikap percaya diri, terbuka, perhatian terhadap segala hal, senantiasa mencari terobosan baru, cerdas, penuh dengan pertimbangan, mampu menjalin komunikasi, suka bersaing yang sehat dan tidak pernah takut dengan adanya perubahan. Sebagai langkah untuk meningkatkan etika dalam bekerja adalah ditumbuhkan kesadaran, semangat, kemauan, komitmen, inisiatif, produtif, peningkatan dan wawasan dari para karyawan. Selain itu, upaya lain yang perlu dilakukan untuk meningkatkan etika kerja karyawan adalah dengan memberikan pembinaan disiplin, pemberian motivasi, pemberian penghargaan dan persepsi yang merupakan proses untuk mengetahui beberapa hal melalui pancaindra. Seorang karyawan harus mampu melaksanakan tugas-tugasnya dengan mengembangkan prinsip cooperative (kerjasama), keterbukaan dan commitment (memiliki niat kuat) dan consistence (istiqomah).

\section{Kepemimpinan}

Kepemimpinan adalah kemampuan seseorang untuk mempengaruhi orang lain, 
dalam hal ini para bawahannya sedemikian rupa sehingga orang lain itu mau melakukan kehendak pimpinan meskipun secara pribadi hal itu mungkin tidak disenangi.

Dalam kepemimpinan terdapat proses mempengaruhi aktivitas yang diorganisir dalam suatu kelompok dalam usahanya untuk mencapai tujuan yang telah ditetapkan. Kepemimpinan harus melibatkan orang lain (bawahan atau pengikut) untuk menerima arahan dari pimpinan, untuk mempertegas status pemimpin dan memungkinkan terjadinya proses kepemimpinan.

Menurut Hasibuan (2016) pimpinan adalah seseorang dengan wewenang kepemimpinannya mengarahkan bawahannya untuk mengerjakan sebagian dari pekerjaannya dalam mencapai tujuan. Seorang pimpinan harus mempunyai peran manajerial meliputi peran antarpersonal, peran informasional dan peran pengambil keputusan. Dalam peranannya sebagai peran antarpersonal harus melakukan tugas sebagai penggerak dan penghubung antar karyawan sebagai bentuk dukungan untuk pencapaian kinerja. Peran informasional yang dapat ditunjukan oleh seorang pimpinan adalah sebagai peran pemantau dan penyalur untuk meneruskan informasi kepada para karyawan. Peran lain dari pemimpin adalah peran pengambilan keputusan. Peran ini terkait dengan kemampuan pimpinan dalam menyelesaikan berbagai masalah yang tak terduga, dengan mendiskusikan berbagai persoalan dan negosiator yang baik demi keuntungan bersama.

Setiap pemimpin dalam menjalankan tugas kepemimpinannya selalu mempunyai ciri atau gaya yang khas. Gaya kepemimpinan merupakan perilaku atau cara yang dipilih atau yang dipergunakan pimpinan dalam mempengaruhi pikiran, perasaan, sikap dan perilaku para anggota organisasi atau bawahannya. Beberapa gaya kepemimpinan yang secara umum, adalah: kepemimpinan instruksi, kepemimpinan konsultasi, dan kepemimpinan delegasi. Gaya kepemimpinan instruksi bersifat instruktif dengan ciri komunikasi satu arah. Pimpinan dengan gaya ini, membatasi peranan bawahan dan memberitahu mereka tentang apa, bagaimana, dan dimana melakukan pekerjaan. Semua hal yang berkaitan dengan pemecahan masalah dan keputusan dilakukan pimpinan, bawahan hanya melaksakan tugas sesuai instruksi. Gaya kepemimpinan konsultasi sifatnya konsultatif atau disebut dengan gaya dokter dengan gaya ini pemimpin banyak memberikan arahan dan mengambil hampir semua keputusan. Komunikasi yang terjadi adalah dua arah dengan menyimak gagasan bawahan, walaupun pemecahaan masalah dan pengambilan keputusan masih dilakukan oleh pimpinan. Gaya kepemimpinan partisipasi sifatnya partisipatif dan pimpinan mengikutsertakan bawahan dalam pemecahaan masalah dan pengambilan 
keputusan. Komunikasi dua arah ditingkatkan dan pemimpin lebih banyak mendengarkan dengan aktif dan tidak lagi memberikan instruksi. Gaya kepemimpinan delegasi sifatnya mendelegasikan yang disebut dengan gaya bebas karena pemimpin dan bawahan hanya mendiskusikan batasan masalah bersama-sama sehingga ada kesepakatan. Proses pengambilan keputusan didelegasikan kepada bawahan. Dalam gaya kepemimpinan ini, pemimpin memberikan kesempatan luas bagi bawahan untuk melaksanakan tugasnya.

Beberapa fungsi pimpinan yang harus diketahui yaitu: fungsi pimpinan sebagai: perencanaan, pengorganisasian, penggerak, dan pengawasan. Seorang pemimpin yang baik memiliki disiplin kerja yang baik, wibawa, mampu berpikir rasional, tanggung jawab, mampu bekerja sama dan memiliki kesetiaan kepada perusahaan.

\section{Profesionalisme}

Profesionalisme adalah suatu kemampuan dan keterampilan yang dimiliki seseorang dalam melakukan kegiatan atau pekerjaan sesuai dengan bidang keahliannya. Suatu organisasi agar dapat bekerja secara efisien dibutuhkan orang yang mempunyai kecakapan yang dibutuhkan dalam pelaksanaan tugas-tugasnya. Seorang yang mempunyai profesionalisme yang tinggi akan menunjukkan hasil kerja yang sesuai dengan standar teknis atau etika sebuah profesi (sebagai karyawan). Profesionalisme adalah pilar yang akan menempatkan karyawan sebagai mesin efektif bagi perusahaan dan sebagai parameter kecakapan karyawan dalam bekerja secara baik.

Karyawan yang profesional adalah orang-orang yang diandalkan dan dipercaya karena mereka mempunyai keahlian, terampil, mempunyai pengetahuan, tanggung jawab, tekun, disiplin dan serius dalam menjalankan tugasnya. Profesionalisme karyawan ditentukan tingkat kemampuannya yang tercermin pada perilakunya sehari-hari dalam organisasi/perusahaan.

Kemampuan karyawan yang tinggi akan mengarah pada pencapaian tujuan perusahaan, sebaliknya apabila tingkat kemampuan karyawan rendah maka tujuan perusahaan akan lambat tercapainya.

Menurut Atmosoeprapto profesionalisme adalah cerminan dari kemampuan (competency), yaitu memiliki kemampuan (knowledge), keterampilan (skill), bisa melakukan (ability), ditunjang dengan pengalaman (experience) yang tidak mungkin muncul tiba-tiba tanpa melalui perjalanan waktu.

Menurut Kurniawan

profesionalisme menyangkut kecocokan antara kemampuan yang dimiliki oleh birokrasi dengan kebutuhan tugas. Setiap karyawan yang professional akan mengandung aspek-aspek berikut:

a. Potensial, bahwa karyawan harus mempunyai memiliki potensi-potensi 
yang bersifat dinamis dan terus berkembang.

b. Profesionalisme, bahwa karyawan harus memiliki kemampuan dan keterampilan kerja atau kejujuran.

c. Fungsional, bahwa karyawan harus melaksanakan tugas dan fungsinya secara tepat guna.

d. Operasional, bahwa karyawan harus dapat mendayagunakan kemampuan dan keterampilannya dalam proses dan prosedur pelaksanaan kegiatan kerja.

e. Personal, bahwa karyawan harus memiliki sikap kepribadian yang menunjang pekerjaan.

f. Produktivitas, bahwa karyawan harus memiliki motif berprestasi dengan berupaya bekerja dengan baik dengan hasil yang baik.

Profesionalisme yang tinggi ditunjukkan oleh besarnya keinginan untuk selalu meningkatkan dan memelihara imej profesion melalui perwujudan perilaku profesonal. Bentuk perwujudannya dapat dilihat pada penampilan, cara berbicara, penggunaan bahasa, sikap, hubungan dengan orang lain.

\section{Kinerja}

Kinerja adalah hasil kerja baik secara kualitas maupun kuantitas yang dicapai oleh seorang pegawai dalam melakukan tugas sesuai dengan tanggung jawab yang diberikan kepadanya. Kinerja diartikan kesediaan seseorang atau kelompok orang untuk melakukan suatu kegiatan, dan menyempurnakannya sesuai tanggung jawabnya dengan hasil seperti yang diharapkan. Mangkunegara (2005:67).

Kinerja menurut John M. Echols dan Hassan Shadily (1984:425) adalah "perform berarti melakukan atau menyelenggarakan, dan performance berarti perbuatan". Faktorfaktor yang mempengaruhi kinerja karyawan adalah: 1) Faktor individu, yaitu kemampuan dan keterampilan (mental dan fisik), latar belakang (pengalaman, keluarga, dst), dan demografis (umur, asal-usul, dll). 2) Faktor organisasi, adalah sumber daya, kepemimpinan, imbalan (kompensasi), struktur organisasi, dan diskripsi pekerjaan (jobdescription). 3) Faktor psikologis, ialah persepsi, sikap, kepribadian, pola belajar, dan motivasi. (Gibson, et all, 1995:375)

Kinerja karyawan secara objektif dan akurat dapat dievaluasi melalui tolak ukur tingkat kinerja. Pengukuran tersebut berarti memberi kesempatan bagi para karyawan untuk mengetahui tingkat kinerja mereka. Sedarmayanti (2001:51), mengemukakan indikator-indikator kinerja yaitu sebagai: Kualitas Kerja (Quality of work), Ketetapan Waktu (Pomptnees), Inisiatif (Initiative), Kemampuan (Capability) dan Komunikasi (Communication).

Kinerja organisasi adalah totalitas hasil kerja yang dicapai suatu organisasi dan sebagai efektivitas organisasi secara menyeluruh untuk kebutuhan yang ditetapkan 
dari setiap kelompok yang berkenaan melalui usaha-usaha yang sistematik dan meningkatkan kemampuan organisasi secara terus menerus untuk mencapai kebutuhannya secara efektif.

Penilaian kinerja bukan tujuan akhir melainkan alat agar dihasilkan Manajemen yang lebih efisien dan terjadi peningkatan kinerja. Hasil pengukuran kinerja akan memberikan informasi tentang apa yang terjadi, bukan mengapa hal itu terjadi atau apa yang harus dilakukan. Pada suatu perusahaan melakukan penilaian terhadap kinerja karyawan menjadi hal yang diharuskan guna mengukur keberhasilan atau kegagalan pelaksanaan kegiatan/program. Karenanya diperlukan suatu system yang mampu untuk mengukur kinerja dan keberhasilan organisasi.

Adapun tujuan penilaian kinerja adalah untuk mengetahui tingkat pencapaian tujuan organisasi, menyediakan sarana pembelajaran karyawan, memperbaiki kinerja periode berikutnya, memberikan pertimbangan yang sistematik dalam pembuatan keputusan pemberian reward an punishment, memotivasi karyawan dan menciptakan akuntabilitas publik.

\section{Kerangka Pemikiran}

Etika kerja karyawan secara langsung mempunyai pengaruh terhadap peningkatan kinerja. Dari beberapa penelitian, mengatakan bahwa peningkatan etika kerja karyawan akan mempengaruhi peningkatan kinerja karyawan.

Kepemimpinan secara langsung berpengaruh terhadap kinerja karyawan. Keberhasilan suatu perusahaan atau organisasi sangat dipengaruhi oleh peranan seorang pemimpin yang mampu menjalankan kepemimpinan dengan baik. Pada penelitian yang dilakukan oleh G Erlangga (2017) menyebutkan bahwa kepemimpinan mempunyai pengaruh signifikan terhadap kinerja karyawan PT Securindo Packatama Indonesia.

Profesionalisme mempunyai pengaruh terhadap peningkatan kinerja karyawan. Karyawan yang professional akan melakukan tugas dan pekerjaannya dengan sebaikbaiknya dan menghasilkan kinerja yang baik. Semakin tinggi tingkat profesionalisme karyawan maka tingkat kinerja akan semakin tinggi.

Secara simultan etika kerja, kepemimpinan dan profesionalisme mempunyai pengaruh terhadap kinerja. Dengan meningkatkan ketiga factor ini secara bersamaan maka akan semakin besar pengaruhnya terhadap kinerja.

\section{Hipotesis}

Hipotesis yang diajukan dalam penelitian ini adalah:

H1: Etika kerja berpengaruh terhadap kinerja karyawan 
$\mathrm{H} 2$ : Kepemimpinan berpengaruh terhadap kinerja karyawan

H3: Profesionalisme berpengaruh terhadap kinerja karyawan

H4: Etika Kerja, Kepemimpinan dan Profesionalisme secara simultan berpengaruh signfikan terhadap kinerja karyawan.

\section{Metodologi Penelitian}

Penelitian ini dilakukan di PT Lion Air yang beralamat pada Lion Tower Pusat Jalan Gajah Mada No.7 Jakarta Pusat. Waktu pelaksanaan penelitian ini adalah selama 4 (empat) bulan yaitu pada bulan Pebruari s.d. Mei 2018.

Metode dalam penelitian ini adalah deskriftif verifikatif dengan menyajikan gambaran secara terstruktur atas seberapa besar pengaruh etika kerja, kepemimpinan dan profesionalisme terhadap kinerja karyawan. Pada analisis verifikasi bertujuan untuk menguji nilai hipotesis satu variabel sehingga dapat diketahui pengaruh antara satu variabel dengan variabel lain.

Populasi pada penelitian ini adalah karyawan yang PT Lion Air yang bertugas di Kantor Pusat Jalan Gajah Mada Jakarta. Populasi adalah seluruh data yang menjadi perhatian kita dalam suatu ruang lingkup dan waktu yang kita tentukan. Jadi populasi berhubungan dengan data, bukan manusianya. Kalau setiap manusia memberikan suatu data, maka banyaknya atau ukuran populasi akan sama dengan banyaknya manusia.

Menurut Sugiyono (2011:81) "Sampel adalah bagian dari jumlah dan karakteristik yang dimiliki oleh populasi tersebut." Ukuran sampel pada penelitian ini menggunakan Teknik Slovin (Sujarweni dan Endrayanto, 2012:17). Rumus Slovin utnuk menentukan sampel adalah:

$$
\mathrm{n}=\frac{\mathrm{N}}{1+\mathrm{N}(e)^{2}}
$$

Keterangan:

n : Ukuran sampel/jumlah responden

$\mathrm{N} \quad$ : Ukuran populasi

e : Persentase kelonggaran ketelitian kesalahan pengambilan sampel yang masih bisa ditolerir; $\mathrm{e}=0,1$. Jumlah populasi dalam penelitian ini adalah 44 orang, sehingga persentase kelonggaran yang digunakan adalah $10 \%$. Maka untuk mengetahui sampel penelitian, berikut perhitungannya:

44

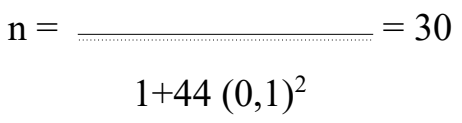

Berdasarkan perhitungan di atas sampel menjadi responden dalam penelitian ini sebanyak 30 orang.

\section{Uji Validitas dan Reliabilitas}

\section{Uji Validitas}

Tujuan uji validitas adalah untuk menguji kevalidan item instrumen penelitian. Validitas item kuesioner ini ditentukan dengan rumus koefisien korelasi Pearson Product Moment melalui uji t yaitu jika $\mathrm{t}$ 
hitung $>t$ tabel dengan taraf kepercayaan 95\% dan dk n-2 maka butir soal dinyatakan valid dan jika sebaliknya maka butir soal tidak signifikan atau tidak valid.

\section{Uji Reliabilitas}

Tujuan uji reliabilitas adalah untuk mengukur ketetapan atau keajegan alat ukur dalam mengukur apa yang hendak diukur. Artinya kapan pun alat ukur tersebut digunakan akan memberikan hasil ukur yang sama. Setiap alat pengukur seharusnya memiliki kemampuan untuk memberikan hasil pengukuran yang konsisten (Ancok dalam Singarimbun dan Effendi, 2011:142144). Cara mencari besaran angka reliabilitas dengan menggunakan metode Cronbach's Alpha. (Nunnally, dalam Ghozali, 2009:42). Suatu konstruk atau variabel dikatakan reliabel jika memberikan nilai Cronbach Alpha $>0,60$.

\section{Metode Analisis Data}

\section{Uji Asumsi Klasik}

Uji asumsi klasik merupakan prasyarat untuk melakukan analisis regresi. Uji asumsi klasik yang dilakukan dalam penelitian ini adalah uji normalitas, uji heterokedsastisitas, uji autokorelasi, dan uji multikolinieritas.

Uji normalitas data bertujuan untuk menguji apakah dalam model sebuah regresi, variabel dependen dan variabel independen atau keduanya terdistribusi secara normal. Untuk mengetahui bentuk distribusi data, bisa dilakukan dengan grafik distribusi dan analisis statistik. Pengujian dengan grafik distribusi dilakukan dengan melihat grafik histogram.

Uji heterokedastisitas bertujuan untuk menguji apakah dalam model regresi terjadi ketidaksamaan varian dari residual satu pengamatan ke pengamatan lainnya. Gejala varians yang tidak sama ini disebut dengan heterokedasisitas, sedangkan adanya gejala residual yang sama dari satu pengamatan ke pengamatan lain disebut dengan hemokedastisitas.

Uji autokorelasi adalah untuk mengetahui apakah dalam sebuah model regresi linier ada korelasi antara kesalahan pengganggu pada periode $t$ dengan kesalahan pada periode $\mathrm{t}-1$.

Uji multikolinieritas bertujuan untuk mengetahui apakah dalam model regresi ditemukan adanya korelasi antar variabel bebas (independen). Model regresi yang baik seharusnya tidak terjadi korelasi di antara variabel independen. Untuk mendeteksi adanya multikolinieritas digunakan nilai Variance Inflation Factor (VIF). Jika $\mathrm{VIF}<0,05$, maka dalam model tidak terdapat multikolinieritas.

\section{Regresi Linear Berganda}

Regresi linear berganda ini bertujuan untuk mengetahui seberapa besar pengaruh etika kerja, kepemimpinan dan profesionalisme secara bersama-sama (simultan) terhadap kinerja. Model yang digunakan adalah: $\mathrm{Y}=\mathrm{a}+\mathrm{b}_{1} \mathrm{X}_{1}+\mathrm{b}_{2} \mathrm{X}_{2}+\mathrm{b}_{3} \mathrm{X}_{3}$.

Keterangan: 
$\mathrm{Y}=$ Skor responden dari $\mathrm{Y}$ (variabel nilai $\mathrm{Y} /$ variabel terikat)

$\mathrm{a}=$ Nilai konstan variabel $\mathrm{Y}$

$\mathrm{b}=$ Koefisien arah regresi

$\mathrm{X}=$ Variabel nilai $\mathrm{X}$ (variabel nilai

$\mathrm{X} /$ variabel bebas

\section{Koefisien Determinasi (Adjusted $\boldsymbol{R}^{2}$ )}

Koefisien determinasi bertujuan untuk mengukur seberapa jauh kemampuan model dalam menerangkan variasi variabel dependen. Nilai koefisien determinasi adalah antara nol sampai satu $\left(0<\mathrm{R}^{2}<1\right)$. Hal ini berarti $\mathrm{R}^{2}=0$ menunjukkan tidak adanya pengaruh antara variabel independen terhadap variabel dependen, bila Adjusted $R^{2}$ semakin besar mendekati 1 menunjukkan semakin kuatnya pengaruh variabel independen terhadap variabel dependen dan bila Adjusted $R^{2}$ semakin kecil bahkan mendekati nol, maka semakin kecil pula pengaruh variabel independen terhadap variabel dependen. Rumus yang digunakan adalah $\mathrm{Kd}=\mathrm{R}^{2} \mathrm{x} 100 \%$.

\section{Uji Hipotesis}

\section{Uji Parsial (Uji t)}

Uji parsial bertujuan untuk menunjukkan seberapa besar pengaruh parsial variabel bebas terhadap variabel terikat. Adapun uji-t menggunakan langkah-langkah sebagai berikut:

$$
\text { Ho }=b_{1}=0 \text {, artinya secara parsial }
$$
tidak terdapat pengaruh etika kerja, kepemimpinan dan profesionalisme terhadap kinerja karyawan.

$\mathrm{Ha}=\mathrm{b}_{1} \neq \square 0$, artinya secara parsial terdapat pengaruh etika kerja, kepemimpinan dan profesionalisme terhadap kinerja karyawan.

Uji Signifikansi terhadap hipotesis ditentukan melalui uji t dengan kriteria pengujian:

- Ho ditolak jika $t$ hitung $>\mathrm{t}$ tabel

- Ho diterima jika $t$ hitung $<\mathrm{t}$ tabel

\section{Uji Simultan (Uji-F)}

Uji simultan bertujuan untuk menunjukkan apakah semua variabel bebas yang dimasukkan dalam model secara simultan mempunyai pengaruh terhadap variabel terikat.

- Ho: $b_{1}=b_{2}=b_{3}=0$, artinya secara simultan tidak terdapat pengaruh etika kerja, kepemimpinan dan profesionalisme terhadap kinerja karyawan.

- Ha: $\mathrm{b}_{1} \neq \square \mathrm{b}_{\square} \neq \square \mathrm{b}_{3} \neq \square 0$, artinya secara simultan terdapat pengaruh etika kerja, kepemimpinan dan profesionalisme terhadap kinerja karyawan.

Uji signifikansi terhadap hipotesis dengan kriteria pengujian:

- Ho ditolak jika F hitung $>\mathrm{F}$ tabel

- Ho diterima jika $F$ hitung $<F$ tabel

Tingkat signifikansi mengunakan nilai alfa $0,05(\alpha=5 \%)$.

\section{PEMBAHASAN}

Uji Validitas

Untuk menilai kevalidan masing-masing butir pertanyaan dapat dilihat dari nilai 
Corrected Item-Total Correlation. Pada uji validitas variabel etika kerja, kepemimpinan, profesionalisme dalam menentukan kinerja karyawan di PT Lion Air dengan melihat pada Corrected Item-Total Correlation pada pengujian reliabilitas, menunjukkan bahwa nilai $r$ hitung lebih besar dari $r$ tabel maka data penelitian dikategorikan layak (sahih). Dari hasil pengujian menunjukkan bahwa secara keseluruhan item pernyataan yang digunakan untuk mengukur etika kerja, kepemimpinan, profesionalisme dan kinerja adalah valid.

\section{Uji Reliabilitas}

Pengujian reliabilitas data digunakan untuk mengukur apakah data yang diuji dapat dipercaya atau dapat diandalkan. Uji reliabilitas instrument dengan menggunakan Cronbach's Alpha. Uji reliabilitas yang dilakukan menunjukkan bahwa etika kerja, kepemimpinan, profesionalisme dan kinerja memiliki nilai Cronbach's Alpha $>0,60$, artinya semua pernyataan dari semua variabel adalah reliabel.

\section{Analisis Data Penelitian}

\section{Uji Asumsi Klasik}

Uji asumsi klasik dalam penelitian ini meliputi Uji Multikolinieritas, Uji Autokorelasi, Uji Heteroskedastisitas, dan Uji Normalitas. Dari hasil Uji Multikolinieritas diketahui bahwa nilai Tolerance dan VIF variabel etika kerja kepemimpinan, profesionalisme dan kinerja memenuhi persyaratan tidak terjadinya multikolinieritas dimana nilai Tolerance $>0,1$ dan $\quad \mathrm{VIF}<10$. Hasil pengujian ini menunjukkan bahwa persyaratan multikolinieritas dalam uji asumsi klasik regresi linier ganda etika kerja, kepemimpinan, profesionalisme dan kinerja terpenuhi. Hasil uji Heteroskedastisitas pada grafik diketahui bahwa titik-titik perpotongan nilai predikte dan residual tersebar tidak beraturan dan tidak membentuk pola tertentu sehingga analisis regresi ganda etika kerja, kepemimpinan, profesionalisme terhadap kinerja tidak memiliki masalah heteroskedastisitas artinya analisis regresi benar-benar linier sehingga persyaratan heteroskedastisitas dalam uji asumsi klasik regresi linier terpenuhi. Hasil Uji Normalitas ditunjukkan pada grafik dimana titik-titik dan nilai residual hasil analisis di sekitar dan mengikuti arah diagonal grafik yang menunjukkan bahwa data variabel etika kerja, kepemimpinan, profesionalisme dan kinerja yang digunakan untuk analisis regresi linier ganda berasal dari data yang berdistribusi normal. Hasil pengujian ini menunjukkan persyaratan normalitas data.

\section{Uji Regresi Linier Berganda}

Nilai persamaan yang dihasilkan $\mathrm{Y}=2,875+0,308 \mathrm{X}_{1}+0,274 \mathrm{X}_{2}+0,418 \mathrm{X}_{3}$ mengartikan bahwa konstanta sebesar 2,875 menyatakan bahwa jika variabel independen dianggap konstan, maka nilai rata-rata kinerja sebesar 2,875. Koefisien regresi $b_{1}$ (etika 
kerja) sebesar 0,308 menyatakan bahwa setiap penambahan pada $b_{1}$ (etika kerja) sebesar 1 (satu) satuan akan meningkatkan kinerja sebesar 0,308 . Koefisien regresi $b_{2}$ (kepemimpinan) sebesar 0,274 menyatakan bahwa setiap penambahan pada $b_{2}$ (kepemimpinan) sebesar 1 (satu) satuan akan meningkatkan kinerja sebesar 0,274. Koefisien regresi $b_{3}$ (profesionalisme) sebesar 0,418 menyatakan bahwa setiap penambahan pada $b_{3}$ (profesionalisme) sebesar 1 (satu) satuan akan meningkatkan kinerja sebesar 0,418.

\section{Koefisien Determinasi $\left(\mathbf{R}^{2}\right)$}

Dari tampilan SPSS Model Summary besarnya nilai korelasi (R) adalah 0,747 masuk dalam kategori Kuat. Dan nilai Adjusted $\mathrm{R}^{2}$ adalah 0,717, hal ini berarti 71,7\% kenaikan kinerja dipengaruhi oleh etika kerja, kepemimpinan, profesionalisme secara bersama-sama, sedangkan 28,3\% dipengaruhi faktor yang lain.

\section{Uji Hipotesis}

\section{Uji Parsial (Uji t)}

Uji parsial t (uji t) digunakan untuk mengetahui pengaruh variabel independen secara parsial terhadap variabel dependen, apakah pengaruh signfikan atau tidak.

Pada hasil uji SPSS, ditemukan nilai seperti pada tabel berikut:
Tabel 1

Uji t-Parsial

Coefficients $^{\mathrm{a}}$

\begin{tabular}{|c|c|c|c|c|c|c|c|}
\hline \multirow[b]{2}{*}{ Model } & \multicolumn{2}{|c|}{$\begin{array}{l}\text { Unstandardized } \\
\text { Coefficients }\end{array}$} & \multirow{2}{*}{$\begin{array}{c}\text { Standardi } \\
\text { zed } \\
\text { Coefficie } \\
\text { nts }\end{array}$} & \multirow[b]{2}{*}{$\mathrm{t}$} & \multirow[b]{2}{*}{ Sig. } & \multicolumn{2}{|c|}{$\begin{array}{c}\text { Collinearity } \\
\text { Statistics }\end{array}$} \\
\hline & B & Std. Error & & & & $\begin{array}{c}\text { Toler } \\
\text { ance }\end{array}$ & VIF \\
\hline $1 \quad$ (Constant) & 2.875 & 4.567 & & .630 & .534 & & \\
\hline Etika Kerja & 308 & .108 & .338 & 2.835 & .009 & .686 & 1.457 \\
\hline Kepemimpinan & .274 & .098 & .292 & 2.761 & .010 & .873 & 1.145 \\
\hline Profesionalisme & .418 & .106 & .473 & 3.866 & .001 & .652 & 1.534 \\
\hline
\end{tabular}

Sumber: SPSS

Pengujian hipotesis dengan uji $t$ untuk uji parsial dengan jumlah responden sebesar 30 orang dengan tingkat signifikansi 5\%, diperoleh nilai sebagai berikut: Pertama, untuk etika kerja diperoleh nilai Sig sebesar 0,009 karena nilai Sig 0,009<0,05 maka Ho ditolak, artinya etika kerja berpengaruh signifikan terhadap kinerja. Kedua, kepemimpinan diperoleh nilai Sig sebesar 0,010, karena nilai Sig 0,010<0,05 maka Ho ditolak, artinya kepemimpinan berpengaruh signifikan terhadap kinerja. Ketiga, untuk profesionalisme diperoleh nilai Sig sebesar 0,001, karena nilai Sig 0,001<0,05, maka Ho ditolak, artinya profesionalisme berpengaruh signifikan terhadap kinerja. Artinya semua hipotesis yang diajukan dapat dibuktikan kebenarannya.

\section{Uji Simultan (Uji F)}

Uji simultan ini bertujuan untuk mengetahui apakah semua variabel independen atau bebas yaitu etika kerja, kepemimpinan, profesionalisme secara bersama-sama (simultan) berpengaruh 
terhadap variabel dependen (terikat) yaitu kinerja. Uji simultan ini dapat dilihat pada tabel berikut:

Tabel 2

Uji F-Simultan

ANOVA $^{\mathrm{b}}$

\begin{tabular}{l|r|r|r|r|r|}
\hline Model & $\begin{array}{r}\text { Sum of } \\
\text { Squares }\end{array}$ & df & $\begin{array}{r}\text { Mean } \\
\text { Square }\end{array}$ & F & Sig. \\
\hline $1 \quad$ Regression & 257.953 & 3 & 85.984 & 25.546 & $.000^{\mathrm{a}}$ \\
Residual & 87.514 & 26 & 3.366 & & \\
Total & 345.467 & 29 & & & \\
\hline
\end{tabular}
a. Predictors: (Constant), Profesionalisme, Kepemimpinan,
Etika Kerja
b. Dependent Variable:
Kinerja
Sumber: SPSS

Pada tabel Anova atau F test diperoleh nilai F hitung sebesar 25,546 dengan nilai Sig sebesar 0,000. Karena probabilitas jauh lebih kecil dari 0,05 maka model regresi dapat digunakan untuk memprediksi bahwa etika kerja, kepemimpinan dan profesionalisme secara simultan berpengaruh signifikan terhadap kinerja karyawan PT Lion Air.

\section{KESIMPULAN}

\section{Simpulan}

Dari hasil penelitian dapat ditarik kesimpulan sebagai berikut:

a. Etika kerja secara parsial berpengaruh positif dan signifikan terhadap kinerja karyawan PT Lion Air. artinya bahwa setiap ada peningkatan pada etika kerja akan diikuti oleh peningkatan kinerja karyawan. Dengan meningkatkan etika kerja karyawan maka PT Lion Air akan mendapatkan kinerja tinggi dari karyawan. b. Kepemimpinan secara parsial berpengaruh positif dan signifikan terhadap kinerja karyawan PT Lion Air. Artinya bahwa semakin tinggi kepemimpinan maka kinerja karyawan akan semakin tinggi pula.

c. Profesionalisme secara parsial berpengaruh positif dan signifikan terhadap kinerja karyawan PT Lion Air. Artinya jika profesionalisme meningkat maka kinerja karyawan akan ikut meningkat dan sebaliknya apabila profesionalisme menurun maka kinerja karyawan ikut menurun.

d. Hasil penelitian membuktikan bahwa secara simultan etika kerja, kepemimpinan, dan profesionalisme berpengaruh terhadap kinerja karyawan PT Lion Air. Dari nilai Adjusted R Square sebesar 0,717, artinya bahwa ketiga variabel independen memberikan pengaruh/kontribusi sebesar $\quad 71,7 \%$ terhadap peningkatan kinerja, selebihnya yaitu sebesar 28,3\% dipengaruhi oleh faktor lain.

\section{Saran}

a. Peningkatan etika kerja karyawan PT Lion Air harus lebih ditingkatkan agar ke depannya kinerja karyawan meningkat sesuai dengan harapan. Untuk mendapatkan kesuksesan dalam karir hendaknya karyawan meningkatkan etika kerja dengan membina diri meningkatkan kesadaran, 
semangat, kemauan, komitmen, inisiatif, produktif dan wawasan.

b. Kepemimpinan pada PT Lion Air terbutki berpengaruh terhadap peningkatan kinerja karyawan. Bentuk kepemimpinan yang ideal sangat diharapkan oleh para karyawan dan perusahaan sehinggan pemimpin yang ada bisa menjadi teladan, pengayom, pendukung, penyemangat, penuh inovasi dan selalu menunjukan tanggung jawab pada tugas.

c. Profesionalisme karyawan PT Lion Air harus menjadi prioritas utama untuk ditingkatkan karena terbukti berpengaruh paling besar terhadap peningkatan kinerja karyawan PT Lion Air. Pada diri karyawan perlu peningkatan tanggung jawab, sikap proaktif, rasa cinta pada perusahaan, kesetiaan atau loyalitas, menerapkan nilai-nilai etis, mau belajar dari kesalahan, serta terbuka atas semua kritik dan saran.

d. Peningkatan kinerja perlu ditinjau lagi dari faktor lainnya, selain dari etika kerja, kepemimpinan dan profesionalisme. Namun demikian, dengan penelitian ini bisa dijadikan masukan untuk kebijakan ke depan agar PT Lion Air lebih mengutamakan peningkatan profesionalisme, yang kemudian diikuti oleh peningkatan etika kerja dan kepemimpinan.

\section{DAFTAR PUSTAKA}

A.A. Anwar Prabu Mangkunegara, 2015. Manajemen Sumber Daya Manusia Perusahaan. PT Remaja Rosdakarya. Bandung

A.A. Anwar Prabu Mangkunegara, 2012. Evaluasi Kinerja SDM, Cetakan keenam, Refika Aditama, Bandung

Achmad Zaenudin, 2009. Manajemen Sumber Daya Manusia, Cetakan Kedua, Penerbit Fajar, Jakarta

Edi Sutrisno, 2009. Manajemen Sumber Daya Manusia, Penerbit Prenada Media, Jakarta

Dessler Gary, 2015, Human Resource Management, Global Edition, Person Higher Education

Ghozali, Imam. 2009. Aplikasi Analisis Multivariate dengan Program SPSS, Edisi Keempat, Badan Penerbit Universitas Diponegoro, Semarang

Gujarati dan Dawn CP. 2009, Basic Economic 5th Edition Mc Graw-Hill; New York

Harianja, Marihot Tua Efendi, 2009. Manajemen Sumber Daya Manusia, Cetakan Kelima, Penerbit Grassindo, Jakarta

Hasibuan, Malayu, S.P., 2016. Organisasi dan Motivasi, Edisi Revisi, Penerbit Bumi Aksara, Jakarta

Husein Umar, 2008. Metode Penelitian untuk Skripsi dan Tesis Bisnis, EdisiKedua, Penerbit Raja Grafindo Persada, Jakarta

Herman Sofyandi, 2008. Manajemen Sumber Daya Manusia, Cetakan Petama,Graha Ilmu, Yogyakarta 


\section{JURNAL M-PROGRESS}

Marwansyah, 2016. Manajemen Sumber Daya Manusia, Edisi Dua, Cetakan Keempat, Alfabeta, Bandung

Moeheriono, 2014. Pengukuran Kinerja Berbasis Kompetensi, Edisi Revisi, PT Rajagrafindo Persada, Jakarta

Rivai, Veithzal, 2010. Manajemen Sumber Daya Manusia untuk Perusahaan:dari Teori ke Praktek, Penerbit PT. Raja Grafindo Persada, Jakarta

Robbins, Stephen P., dan Timothy A. Judge, 2008. Perilaku Organisasi (Organizational Behavior), Edisi Keduabelas, Penerjemah Diana Angelica, Penerbit Salemba Empat, Jakarta

Sinamo, Jansen, 2010. Delapan Etos Kerja Profesional. Institut Mahardika, Jakarta

Singaribuan, Masri dan Effendi, 2011. Metode Penelitian Survei, LP3ESD, Jakarta

Singgih Santoso, 2011. Aplikasi Excel dalam Statistik Bisnis, Cetakan Keempat,Penerbit Elex Media Komputindo, Jakarta.
Sedarmayanti, 2016. Manajemen Sumber Daya Manusia Reformasi Birokrasi dan Manajemen, Cetakan Ke-15, Penerbit Refika Aditama, Bandung

Sugiyono, 2010. Metode Penelitian Kuantitatif Kualitatif dan $R \& D$, Edisi 10, Penerbit Alfabeta, Bandung.

Sugiyono, 2014. Metode Penelitian Bisnis, Alfabeta, Bandung

Sujarweni, V.W., \& Endrayanto, 2012. Statistika untuk Penelitan, Graha Ilmu, Yogyakarta.

Sulistiyani, Ambar Teguh dan Rosidah, 2009. Manajemen Sumber Daya Manusia, Penerbit Graha Ilmu, Yogyakarta.

T. Hani Handoko, 2011. Manajemen Sumber Daya Manusia, BPFE, Yogyakarta.

Wibowo, 2011. Manajemen Kinerja, Rajawali Pers, Jakarta

Wirawan, 2009. Evaluasi Kinerja Sumber Daya Manusia. Salemba Empat. Jakarta 